\title{
Leadership Practices and Professional Needs Among School Principals: A Phenomenological Study
}

\author{
Fernando A. Dones,Jr. \\ fernandojr.dones@yahoo.com /fernando.dones002@deped.gov.ph \\ Schools Division of Siargao, Dapa, Surigao del Norte, 8417, Philippines
}

\begin{abstract}
This phenomenological research project was conducted to explore the leadership practices and professional development needs of secondary school principals. It aimed to articulate the lived experiences and characteristics of school principals as curriculum leaders and school managers.

The participants for this study were the 5 (five) Secondary School Principals of Secondary Schools of Division of Siargao who already 5 (five) years and above experience in have handling a school. The participants were chosen by purposive sampling.

The methods utilized in this study include direct observation, interview and document analysis. Also important in this study was the utilization of triangulation. Mertler (2006) describes triangulation as an invaluable aspect of qualitative research, allowing the researcher to connect various sources of data and establish trustworthy findings with as little bias as possible.

This study was guided by the three grand tour questions. The first grand tour question which had three subquestions divulged the lived experiences that secondary school principals encompass in leadership practices. The second grand tour question revealed the professional characteristics and professional needs of the secondary school principals in their role as curriculum leaders and school managers. The last grand tour question was able to expose the emerging themes that can be drawn from the prevailing codes of the lived experiences of the successful school principal.

The researcher identified six thematic patterns that were relevant to the research topic. The six predominant themes that emerged were: school principals focused on managing teachers and improving school's feature, school principals created a motivating and engaging learning environment for teachers and students, school principals established sustainable linkages and partnerships with stakeholders, school principals utilized results of assessment in managing performance, school principals exhibit mutual understanding of an effective school leader and school principals expressed the need for professional development.

Based on the findings, school principals may consider the emerging themes that were drawn from this study to be applied in their respective administrations. These themes were claimed effective by the seasoned school principal participants hence they are believed to be reliable and significant. Moreover, future research could also be conducted which will replicate this study that would determine how well the findings of this study hold up under different demographic circumstances. It would be especially interesting to conduct a similar study in an area of the country with a larger sample size to allow future researchers to gather richer, varied and comprehensive data of successful school principals.
\end{abstract}

Published by IJRP.ORG. Selection and/or peer-review under responsibility of International Journal of Research Publications (IJRP.ORG)

Keywords: leadership practices; professional needs; phenomenology

\section{Introduction}

\subsection{Background of the Study}


School principals play multifarious leadership roles and functions in setting the direction for schools to be productive workplaces conducive to learning environments. Successful school leadership requires principals to be flexible and dynamic to be functional in a rapidly changing educational bureaucracy. Consequently, the success and failure of the school's development programs and projects are dependent on the school principal's leadership practices.

Secondary schools face different issues and concerns that school managers need to deal with their effective and efficient running. The poor academic performance of students, increasing dropout rates, limited resources, and discipline are the commonly identified adversities which could greatly affect the entire school when not responded accordingly. In the study of Canivel (2010), advances and changes in technology, science, values, environment, and international relationship also hold different challenges and adversities in education. How a leader responds to these challenges not only affects the leader's performance but also the performance of those being led.

In 2015, the result of the National Qualifying Examination for School Heads (NQESH) as administered by National Educators Academy of the Philippines (NEAP) obtained only 2,195 out of the total 18,574 test takers who passed the exam or have met the cut-off score of Percentile 90 based on the total standard score obtained by the examinees in all performance domains covered by the examination. In Caraga Region alone, only 90 of the 882 examinees passed the said qualifying exam (DepEd Memorandum No. 11, s. 2016). This implies that some in-service and aspiring school administrators do not have enough skills and competencies which can be attained through attending trainings, actual experience, capacity buildings and other exposures.

To address this problem, DepEd Division of Siargao sent school heads and administrators to attend training programs in 2009. One of which is the Instructional and Curricular Excellence in School Leadership for Southeast Asia (ICeXCELS). It is a short course package of SEAMEO INNOTECH for school administrators in developing instructional and curriculum development leadership. It addresses the need to develop and strengthen the school heads' role as an instructional leader in promoting or improving the quality of teaching or learning in their schools.

DeJaeghere, Williams, and Kyeyune (2008) argued that professional development programs for school leaders should go beyond the government-initiated programs that will provide them with adaptive skills to lead complex and changing school environment. However, in the study of Williams and Cunnings (2005), they pointed out that principals are far less likely to receive training for their management functions at the beginning of their career. This suggests that some school principals are not adequately prepared to cope with the complex issues pertaining to management and teaching-learning needs of their respective schools.

Stoltz (2008) stressed the importance of conducting research among school leaders to find out how they respond to different issues that are carried along with their responsibility and role as school managers. This means that the way the school heads deal with the adversities brought about by both external and internal factors could greatly affect their multifarious role as school managers which could result in inability of fulfilling their potential which in consequence, lowers their performance in terms of resourcefulness, adjustment to change with new ideas, problem-solving, decision-making, optimism, and healthiness.

Principals who are successful must develop skills to cope and thrive as new roles and responsibilities are placed on them through laws and accountability expectations (Faklaris, 2013). In the local context, school heads are provided with the position competency profile stipulating their duties and functions before they assume responsibilities to their respective stations. Hence, school leadership has long been the focus of Western research but in the local context, no studies have been extensively done that explored the professional development needs of the secondary school administrators (Khan, 2010).

Hence, through a phenomenological study, it is hoped that this research will provide knowledge and information about leadership practices and professional needs of secondary school principals as a basis for 
education reform programs. Further, this study will give a clear understanding of the lived experiences of those in the field to guide future training as well as professional development opportunities for existing leaders.

\section{Statement of the Problem}

The study explored the leadership practices and professional development needs of secondary school principals in the Department of Education for SY 2016-2017. It aimed to articulate the lived experiences and characteristics of school principals as curriculum leaders and school managers.

Specifically, the study sought to answer the following research questions:

1. What leadership practices are exhibited by the principals in their lived experience?

2. What are the professional characteristics and needs of the secondary school principals in their role as curriculum leaders and school managers?

3. What are the emerging themes that can be drawn from the prevailing codes of the lived experiences of the successful school principals?

\section{Delimitation of the Study}

This study gathered data from the five (5) secondary school principals of Dapa National High School, Del Carmen National High School and Gen. Luna National High School, Union National High School and Sapao National High within the Schools Division of Siargao. School principals with 5 (five) years and above experience as school leaders and curriculum managers were chosen in this study. Purposely, the number of years was carefully investigated in this study because experienced principals can provide deep expression of rich and realistic experiences as far as leadership practices are concerned.

The participants of the study were delimited to five school principals. This sample size certainly is small. However, this study is phenomenological in nature. The present study used a more rigorous data gathering procedure since it involves methods of triangulation. Data came from an in-depth interview, document review and direct observation. This is one way of establishing validity in gathering the data.

\section{Definition of Terms}

For the purpose of clarity, the following terms are defined theoretically and or operationally.

Phenomenology. Phenomenology is a strategy of inquiry in which the researcher identified the essence of human experiences about a phenomenon as described by participants (Creswell, 2009).

Professional development. Professional development means a comprehensive, sustained, and intensive approach to improving teachers' and principals' effectiveness in raising student achievement (Hirsh, 2009). Guskey (2000) defined professional development as those processes and activities designed to enhance the professional knowledge, skills, and attitudes of educators so that they might, in turn, improve the learning of students.

\section{Theoretical Framework}

\section{Skills Theory}

This study is anchored on skills theory which states that learned knowledge and acquired skills, and abilities are significant factors in the practice of effective leadership. Skills theory argues that learned skills, a developed style, and acquired knowledge, are the real keys to leadership performance. A strong belief in skills theory often demands that considerable effort and resources be devoted to leadership training and development (Wolinski, 2010). 


\section{Contingency Theory}

Another equally important anchorage in this study is the contingency theory of leadership which focuses on variables related to the environment that might determine which style of leadership is best suited for a particular work situation. According to this theory, no single leadership style is appropriate in all situations. Success depends on some variables, including leadership style, qualities of followers and situational features (Charry, 2012). To provide support to these theories, this study also considered leadership models pertinent to exploring further leadership practices of school heads. The quality of leadership makes a significant difference to school and student outcomes (Bush, 2002). Specifically, this study is also anchored on the concepts of educational leadership notably categorized by Bush and Glover (2002). They described these categories as managerial, transformational, participative and instructional leaderships.

\section{On Leadership}

Leadership is a process of combining efforts and a subtle process of mutual influence fusing thoughts, feelings, and actions to produce cooperative effort in the service of purposes and values embraced by both the leader and the led (Bolman \& Deal, 2003). Contrastingly, management and leadership are not different concepts since the jobs of the managers are operation-oriented, whereas the jobs of leaders are vision-oriented (Memon \& Bana, 2005).

\section{On School Principal Leadership Practices}

Researchers have investigated various approaches to leadership practice. Accordingly, Coleman and Earley, (2005) reviewed broad categories or styles of leadership which represent the models of leadership in educational institutions. These include instructional leadership, transformational leadership, participative leadership, and managerial leadership.

\section{Methodology}

\subsection{Research Design}

The researcher of this study chose a qualitative research design specifically phenomenology because the study dealt with individuals serving as school principals. Phenomenology is known as an educational qualitative research design (Ponce, 2014; Creswell, 2013, Marshall \& Rossman, 2010). It is a design of inquiry coming from philosophy and psychology in which the researcher describes the lived experiences of individuals about a phenomenon as described by the participants. This description culminates in the essence of the experiences for several individuals who have all experienced the phenomenon. This design has strong philosophical underpinnings and typically involves conducting interviews (Giorgi, 2009; Moustakas, 1994).

Being a phenomenological qualitative research in nature, this study is closely anchored to the qualitative study of Faklaris (2013), though from the foreign setting, is tapped as an exemplar of this present project since it researched about the principals were able to positively impacted in schools.

This study explored the experiences, perceptions, insights, and opinions of the secondary school principals to determine their common educational leadership practices and professional needs as school managers and instructional leaders. Creswell (2008) identified the major procedures for conducting a phenomenological study that includes identifying the common experience shared by several individuals, acknowledging the philosophical assumptions of the phenomenological tradition, collecting data, analyzing the data, and writing a report.

As such they are powerful for understanding subjective experience, gaining insights into people's motivation and actions, and cutting through the clutter of taken-for-granted assumptions and conventional wisdom. Pure phenomenological research seeks essentially to describe rather than explain and to start from a perspective free from hypotheses or preconceptions (Faklaris, 2013). 


\subsection{Participants of the Study}

The participants for this study were the five (5) Secondary School Principals of Secondary Schools of Division of Siargao who already five (5) years and above experience in have handling a school. The participants were chosen using purposive sampling. Purposive sampling is characterized by the incorporation of specific criteria met by the participants at the moment of selection (Diaz, 2015).

The researcher deliberately selected the participants who could bring richness and depth to an understanding of the phenomenon of the study (Creswell, 2007). The researcher chose the participants based on their experiences, location of the schools they were handling, and the school's financial status since these aspects somehow influence the leadership practices of the school principals. The location was also considered to ensure that the five largest municipalities in the island are represented.

Phenomenological research typically involves a small number of participants (Boyd, 2001). It is maintained that the five participants are acceptable sample size of this study to effectually excavate the lived experiences from very common events to the most delicate topmost secrets and victories of the school principals.

\section{Summary, Findings, Conclusions and Recommendations}

\subsection{Summary}

This study explored the lived experiences of secondary school principals' leadership practices. It employed the phenomenological method which allowed the researcher to investigate the experiences, stories, opinions and professional needs of the chosen school principals who practiced their duties and responsibilities as school managers and curriculum leaders.

This study was guided by the three grand tour questions. The first grand tour question which had three subquestions revealed the leadership practices exhibited in the lived experiences of the principals. The second grand tour question exposed the professional characteristics and professional needs of the secondary school principals in their role as curriculum leaders and school managers. The last grand tour question was able to expose the emerging themes that can be drawn from the prevailing codes of the lived experiences of the successful school principal.

The study was conducted at the Schools Division of Siargao. Secondary School Principals with five and above experience in handling school. The participants were chosen through purposive sampling. They signified interest and approval to take part in this research project through personal confirmation and letter of consent approved by the superintendent. They were assured that their participation would be treated with utmost confidentiality and anonymity throughout the study and beyond. Only secondary school principals were selected as samples of this study, yet this small sample size is acceptable since this research project is a phenomenological qualitative research by nature.

Data collection did not begin until the Graduate School Dissertation Committee members approved the research methods and procedures. The data gathering instruments were checked and reviewed by the two Education Program Supervisors for content validity considering that the interview questions were adopted from the study conducted in a foreign setting.

\subsection{Findings}

The data indicated that secondary school principals had employed instructional, transformational, managerial, and participative leadership practices in carrying out their duties and responsibilities. Also, this study attempted to determine the educational leadership practices of the school principal regarding school management duties and responsibilities. Straight from their responses, the participants expressed that by following the unified vision-mission of DepEd for it served as their guidepost in leading a direction for their 
school, by providing technical assistance and support to their teachers and by involving teachers in making an important decision about management.

This study identified the educational practices of school principals in terms of their curriculum and instructional duties and responsibilities. Each principal described their regular conduct of classroom observations and in assessing teachers' performance using the IPCRF (Individual Performance Commitment Review Form). They also used the results of NAT (National Achievement Test) to determine the performance of the teachers and the school in general. The assessment results were used as baseline information in coming up with a development program which includes the improvement of school learning climate.

This study also explored the educational leadership practices of secondary school principals regarding their communication and interpersonal duties and responsibilities. The findings indicated that school principals acknowledged the importance of open communication and being a 24/7 principal. They also assured that their teachers could approach them anytime whenever they have something to open with or if they have problems related to their work. They also recognized efforts of teachers for every success they have attained or the success of the school at large as a way of giving motivation. On the other, the participants also recognized the indispensable roles of stakeholders as partners in all the school's undertakings.

Moreover, the study categorized the characteristics and the professional needs of the school heads. Each school head expressed that an effective leader must be committed and a visionary leader. He/she must know how to protect his/her teachers from the external pressures from the community. On the other hand, school principals conveyed that they still need more training about school management. They also believed that by reading, researching, and benchmarking could enhance their craft as school managers and curriculum leaders.

Lastly, the researcher identified six thematic patterns that were relevant to the research topic. The six predominant themes that emerged were: school principals focused on managing teachers and improving school's feature, school principals created a motivating and engaging learning environment for teachers and students, school principals established sustainable linkages and partnerships with stakeholders, school principals utilized results of assessment in managing performance, school principals exhibit mutual understanding of an effective school leader and school principals expressed the need for professional development. Related studies with similar and contrasting findings are herein presented to provide support to the analysis of each theme and sub-theme.

\subsection{Conclusions}

Based on the findings, the following conclusions were drawn:

1. Secondary School Principals' lived experiences encompassed instructional, transformational, participative and managerial leadership practices as far as their duties and responsibilities are concerned.

2. Secondary School Principals displayed characteristics of an effective school manager and curriculum leaders.

3. There are six predominant themes emerged, namely: school principals focused on managing teachers and improving school's feature, school principals created a motivating and engaging learning environment for teachers and students, school principals established sustainable linkages and partnerships with stakeholders, school principals utilized results of assessment in managing performance, school principals exhibit mutual understanding of an effective school leader and school principals expressed the need for professional development.

\subsection{Recommendations}

Based on the findings, the researcher strongly recommends the following:

1. Principals should explore more educational leadership practices related to school management through research-based and proven effective practices which are applicable in their own context. 
Thus, they should implement a system so that there will be no overlapping of regular duties and functions.

2. The principal should be responsible enough in assessing the performance of their teachers by following the calendar of the Result-based Performance Management System. Likewise, they should keep a journal in monitoring and supervise the performance of their teachers on how far they have attained their objectives. Means of verifications (MOV) should be used as determining evidence to speak the performance of the teacher.

3. The finding of the study revealed that secondary school leaders did not sufficiently practice selfassessment with stakeholders before planning School Improvement Plan. But a SIP which is developed without undergoing self- assessment with responsible stakeholders may face a great challenge during implementation. Therefore, it is advisable that secondary school leaders need to aware and convince responsible bodies such as SIP committee, parents, teachers, students through continuous discussion and work with them. The DepEd officials should visit the school in a sustainable manner and discuss with school leaders, identify problems, and give technical support including training where it is necessary.

4. School Principals need to search for mechanisms which will enable them to generate their own schools' income rather than waiting for supports extended by the external stakeholders.

5. Motivation is a driving force which may lead the teachers to more success. Therefore, secondary school leaders should emphasize further on teacher's motivation and allocate cash incentives as the reward for this purpose.

6. A finding revealed that secondary school leaders were fairly and economically using the available resources. But the result from interview revealed that still, many schools had a scarcity of financial resources. The result from observation also revealed that some sampled schools had a scarcity of school facilities. Therefore, school leaders in collaboration with proactive stakeholders need to identify problems in the school and should allocate available budgets for the school so that the schools will be successful in realizing a physically conducive to learning environment.

7. School principals may increase social mobilization and networking to potential stakeholders who could provide assistance for the improvement of the school ancillary services which include guidance, medical and dental health services. Moreover, school principals may also widen community linkages to local government units to financially assist school in the procurement of equipment for the existing school laboratories and supplementary instructional materials and ebooks portal for the library.

8. As the finding revealed, secondary school leaders seem to lack adequate leadership core competencies and skills which hinder them to lead the school properly. But school leaders should be competent, skillful, and flexible to use different leadership styles in different situations. Therefore, it is also advised that Human Resource and Development (HRD) should identify the gap and give sustainable training that will capacitate school leaders with competency-based leadership practices. 
9. Future research could also be conducted which will replicate this study that would determine how well the findings of this study hold under different demographic circumstances. It would be especially interesting to conduct a similar study in an area of the country with a larger sample size to allow future researchers to gather richer, varied, and comprehensive data of successful school principals.

\section{References}

[1] Abbasialiya, A. (2010). The Concept of Leadership. Retrieved October 7, 2016, from http://expertscolumn.com/ content/conceptleadership.

[2] Argyris, C. (2011). Organizational traps: Leadership, culture, organizational design. New York, NY: Oxford University Press.

[3] Blankstein, A.M. Houston, P.D and Cole, R.M (2010). Data enhance leadership. Thousand oaks, C.A: Corwin press.

[4] Bennett, N., Crawford, \& Cartwright M. (2003). Effective educational leadership. London: Paul Chapman Publishing.

[5] Bolman, L. G., Deal, T. E. (2003). Reframing organizations: Artistry, choice, and leadership. San Francisco: Jossey-Bass.

[6] Bush T \& Glover D 2002. School Leadership: Concepts and Evidence. National College for School Leadership.

[7] Caldwell B \& Spinks J 1992. Leading the Self-Managing School. London: The Falmer Press.

[8] Charry, K. (2012). Leadership Theories - 8 Major Leadership Theories. Retrieved October 7, 2016 from http://psychology. about.com/od/leadership/p/leadtheories.htm

[9] Coleman, M., \& Earley,P. (2005). Leadership and management in education. New York, Oxford University Press.

[10] Cotton, K. (2003). Principals and student achievement: What the research says. Alexandria, VA: Association for Supervision and Curriculum Development.

[11] Creswell, J.W. (2009). Qualitative inquiry and research design: Choosing among five traditions. Thousand Oaks, CA: Sage.

[12] Dalin, P. (Ed).(1997). Leadership and management theory. (2nd ed). London: Continuum International Publisher.

[13] Darling-Hammond, L., \& Orphanos, S. (2006). Leadership development in California. Stanford, CA: Stanford University.

[14] Day, C. (2007). Successful school principal leadership in times of change: International Perspectives, Dordrecht: Springer.

[15] DeJaeghere, G.J., Williams, R., \& Kyeyune, R. (2008). Ugandan secondary school head teachers' efficacy: What kind of training for whom. International Journal of Educational Development.

[16] DuFour, R., DuFour, R., Eaker, R., \& Karhanek, G. (2010). Raising the bar and closing the gap: Whatever it takes. Bloomington, IN: Solution Tree.

[17] English, F. W. (2008). The art of leadership: Balancing performance and accountability. Thousand Oaks, CA: Sage.

[18] Faklaris, J. (2013) A phenomenological study of principals who transformed a positive impact of school change. Published Dessirtation. Liberty University. Falmer Press.

[19] Giorgi, A. (2009). A Descriptive Phenomenological Method in Psychology: A modified Husserlian Approach. Pittsburgh, PA: Duquesne University Press

[20] Goddard, R. D., \& Miller, R. J. (2010). The conceptualization, measurement, and effects of school leadership: Introduction to the special issue. The Elementary School Journal, 111, 219-225.

[21] Goodstein, L. (2011). Strategic planning: A leadership imperative. Alexandria, VA: American Society for Training and Development.

[22] Guba, E. G., \& Lincoln.Y.S.(1981). Naturalistic inquiry. Beverly Hills, CA: Sage Publications.

[23] Guskey, T. R. (2000). Evaluating professional development. Thousand Oaks, California: Corwin Press.

[24] Hallinger, P. (2003). Leading educational change: Reflections on the practice of instructional and transformational leadership. Cambridge Journal of Education, 33, 329-352.

[25] Hallinger, P. (2008). Methodologies for studying school leadership: A review of 25 years of research using the principal instructional management rating scale. Paper presented at the annual meeting of the American Educational Research Association, New York.

[26] Hallinger, P. and Walker, A. 2015. School Leadership in East Asia: An Analysis of Five Societies. Report prepared for UNESCO's Section of Teacher Development and Education Policies. Paris, France.

[27] Hargreaves, A., \& Goodson, I. (2006). Educational Change Over Time? The Sustainability and Nonsustainability of Three Decades of Secondary School Change and Continuity. Educational Administration Quarterly

[28] Harris, A. (2004) 'Distributed leadership and school improvement: leading or misleading?' Educational management and administration, 32(1), 11-24. 
[29] Harris, A. and Muijs, D. (2005). Improving schools through teacher leadership. Berkshire: Open University Press.

[30] Ibara, E. C. (2010). Perspectives in Educational Administration. Port Harcourt, Nigeria: Rodi Printing and Publishing.

[31] Jenkins, T. (2013). Reflections on Kenneth E. Boulding's The Image: Glimpsing the Roots of Peace Education Pedagogy. Journal of Peace Education and Social justice, 7(1), 27-37.

[32] Khaki, J.A. (2005).Exploring the beliefs and behaviors of effective head teachers in the government and non-government schools in Pakistan.

[33] Khan, T. (2010). Teacher Job Satisfaction and incentives: A case study of Pakistan

[34] Kimball, S. M., \& Milanowski, A. (2009). Examining teacher evaluation validity and leadership decision making within a standards-based evaluation system.Educational Administration Quarterly, 45(1), 34-70.

[35] Knight, J. (2007). Instructional coaching: A partnership approach to improving instruction. Thousand Oaks, CA: Corwin Press.

[36] Kvale, S. and Brinkman, S. (2009). Interviews: Learning the craft of qualitative research interviewing. London: Sage.

[37] Lamb, R. (2013). How can Managers Use Participative Leadership Effectively? Retrieved October 7, 2016, from http://www.task.fm/participative-leadership.

[38] Leithwood, K. (2008).Seven strong claims about successful school leadership. School Leadership and Management, Vol. 28, No. 1, pp. 27-42.

[39] Lunenburg, F. C., \& Ornstein, A. O. (2008). Educational administration: Concepts and practices (5th ed.). Belmont, CA: Wadsworth/Cengage

[40] Lichtman, M. (2012). Qualitative research in education: A user's guide (3rd ed.). Thousand Oaks, CA: Sage Publications.

[41] Lyons, J.E. and Algozzine, B. (2006), "Perceptions of the impact of accountability on the role of principals", Education Policy Analysis Archives, Vol. 14 No. 16, available at: http://epaa.asu. edu/epaa/v14n16/

[42] Marzano, R. J., (2005). School leadership that works: From research to results. Virginia: ASCD.

[43] McDonnell, R. (2011). Essentials of program planning and evaluation. Sudbury, MA: Jones \& Bartlett.

[44] Memon, M. \& Bana, Z. (2005). Pedagogical leadership in Pakistan: Two head teachers from the Northern Areas. In J. Retallick \& I. Farah(Eds.), Transforming schools in Pakistan: Towards the learning community (pp.162-181). Karachi: Oxford University Press

[45] Mertens, D. M. (2005). Transformative paradigm. Journal of Mixed Methods Research.1, (3), 212-225.

[46] Naylor, J. (1999). Management. Harlow, England: Prentice Hall.

[47] OECD. 2005 Improving School Leadership: Guidelines for Country Participation. Paris, OECD.

[48] Oduro, G. K. T. (2007). Distributed leadership in schools. Education Journal, 80, 23-25.

[49] Ololube, N. P., Egbezor, D. E., Kpolovie, P. J., \& Amaele, S. (2012). Theoretical debates on school effectiveness research: lessons for Third World education development agendas. In N. P. Ololube \& P. J. Kpolovie (Eds.), Educational management in developing economies: Cases ' $n$ ' school effectiveness and quality improvement, (pp. 1-18). Saarbucken: Lambert Academic Publishers [Oosterlynck, S. (2011). Bridging the gap between planning and implementation: Turning transformative visions into strategic projects. London, UK: Taylor \& Francis

[50] Pansiri, N.O. (2008). Instructional leadership for quality learning. An assessment of the impact of the primary school management development project in Botswana. Educational Management Administration and Leadership, 36(4), 471-494.

[51] Ponce, O. (2014). Investigación Cualitativa en Educación: Teorías, Prácticas y Debates. Hato Rey: Publicaciones Puertorriqueñas.

[52] Quinn, D.M. (2001). The impact of principal leadership behavior on instructional practice and student engagement. Journal of Educational Administration, 40(5), 447-467.

[53] Robinson, V., Hohepa, M. \& Lloyd, C. (2009) School leadership and student outcomes: identifying what works and why. Best Evidence Syntheses Iteration (BES). New Zealand: Ministry of Education.

[54] Rossman, G. (2003) Learning in the field: An introduction to qualitative research: Thousand Oaks, CA: Sage Publication

[55] Rubin, H.J., \& Rubin,I.S. (2012). Qualitative Interviewing: The Art of Hearing Data (3rd. ed). Los Angeles, CA: Sage.

[56] Sergiovani, T.J. (1998). Leadership as pedagogy, capital development and school effectiveness. International Journal of Leadership in Education, 1(1), 37-46.

[57] Southworth, G. (2009). Learning-centered leadership. In B. Davies (Ed.), The essentials of school leadership (pp. 91-111). London: SAGE.

[58] Stake R.S. (2004). Qualitative Research: Studying How it Works. New York: Guilford Press.

[59] Smith, L. and Riley, D. 2012. School leadership in times of crisis. School Leadership and Management, Vol. 32, No. 1, pp. 57-71.

[60] Spillane, J. P. (2006). Distributed leadership. San Francisco: Jossey-Bass.

[61] Starks, H. \& Trinidad, S. (2007). Choose your method: a comparison of phenomenology, discourse analysis and grounded theory. Qualitative Health Research, 10, 1375.

[62] Stoltz, P. G. (2000). Adversity Quotient: Turning Obstacles into Opportunities. United States: John Wiley and Sons, Inc 
[63] Townsend, T. (2011). Educating school leaders to think and act both locally and globally. International Journal of Leadership in Education, 13(3), 335-348.

[64] UNESCO (2015). From schooling to learning. Paris: UNESCO/ International Institute for Educational Planning.

[65] Vaillant, D. 2015. La gobernanza educativa y los incentivos docentes: el caso de Chile y de Uruguay. Revista Uruguaya de Ciencia Política, Vol. 21, No. 1, pp. 119-139.

[66] Vegafria, J. (2014) Square pegs in a round hole: lived pedagogical experiences of teachers in an out of field teaching. Unpublished Dissertation. Central Mindanao University, University Town, Musuan, Maramag, Bukidnon

[67] Williams, H. J., \& Cummings, K. W. (2005). Policy making for education reform in developing countries, contexts and processes. Lanham: Scare Crow Education.

[68] Wolinski, S. (2010). Leadership Theories. Retrieved October 7,2016, from http://managementhelp.org/blogs/leadership/201 0/04/21/leadership-theories/ 